\title{
OPTIMIZATION METHODS IN PHYSICAL EDUCATION LESSONS FOR GIRLS IN THE SECOND AND THE THIRD GRADES
}

\author{
Almagul Ilyasova, Valery Kovalenko, Zhanymmurat Erzhanov \\ Kazakh National Pedagogical University after Abay, Almaty, Kazakhstan
}

\begin{abstract}
Background. Theoretical analysis of research papers allowed us to establish that physical preparation of pupils in elementary grades as an area of scientific and pedagogical knowledge was not investigated enough. Despite great efforts to cover a lot of questions and undoubted theoretical and practical significance of educational research, it should be noted that the problem of physical education for younger pupils using sports games in the lessons of physical education remains open to theoretical understanding and experimental study. There is a lack of specific studies that reveal the basic trends and ways to optimize the studied phenomenon. Worsening situation in the area of physical training in junior classes and individual indicators of health status in the country encourages looking for scientific solutions of the problem. Research aim was to define the most effective methods of physical education for 8-9-year-old girls, learners of the second and third grades, during physical education lessons including elements of sports games in a comprehensive school.

Methods. Research participants were 64 girls from the second and the third grades. They were divided into 4 groups -3 experimental groups and one control group. During the experiment, group E1 was allotted $75 \%$ of the time of the lesson for training technical actions of sports, group E2 - 50\% in E3-25\%, for the development of physical skills $-25,50$ and $75 \%$ respectively. The effectiveness of the proposed program was estimated by the changes in the indicators of physical development and general physical fitness.

Results and conclusions. Physical development of girls during the school year changed considerably. The most clearly expressed change was noted in the results of the changes in the girls' body weight, from 20.32 to $23.24 \%$ in all groups. No significant differences between the experimental and control groups in terms of physical development were identified. Indicators of general physical fitness for the whole period of the experiment significantly increased in all the groups studied $(p<.05-.001)$. They may be divided into two groups:

- The first group included indicators which were significantly higher in the experimental group E3, where more time was devoted to physical training (running at $30 \mathrm{~m}$, the hand strength) during the physical education lessons;

- The second group included indicators which were significantly higher in the experimental group E1, where more time was devoted to sports (long jump, making a shot, running $3 \times 10 \mathrm{~m}$ ) during physical education lessons.

Thus, the lessons of physical education with elements of sports promoted more intensive development of the overall fitness of girls aged 8-9 years compared to those who attended physical education lessons conducted according to the general curriculum.
\end{abstract}

Keywords: girls in the second and the third grades, physical education class, physical development, physical fitness, sports and games.

\section{INTRODUCTION}

$\mathrm{P}$ hysical training and sports as an important means of education performs a certain social function and becomes an element of lifestyle among the Kazakh people, thus creating favourable conditions for the harmonious personality development (Кульназарова, 2013).

Increasing importance of systematic physical training and sports for all students should be 
considered as a condition to prepare sports reserve and a solution of other problems of physical education for the younger generation (Yang, Telema, Laakgo, Keltikangas-Järvinen, \& Pullli, 2007; Касымбекова, Кошаев, \& Абишев, 2013; Синявский, Власов, \& Сергеев, 2009).

Consideration of the questions of physical education in junior classes revealed the needs for special scientific and pedagogical consideration in developing specific proposals aimed at providing practical tasks related to physical training (Malina, Bouchard, \& Bar-Or, 2004; Бервинова \& Шарабакин, 2005; Минаев, 1989).

Consideration of the physical training problem for students in junior classes during physical training lessons is in accordance with the following scientific approaches:

- School-based physical training (Волков \& Ромашев, 1998);

- Organization and planning of physical training in physical education classes and extra-curricular hours (Gudžinskienė, 2006; Гужаловский, 1987; Юревич \& Мусатаев, 2013);

- Development of physical skills for schoolaged children (Bar-Or, 1996; van Praag, 2000; Turley, 1997; Бальсевич, 2000).

Theoretical analysis of research papers allowed us to establish that physical preparation of pupils in elementary grades as an area of scientific and pedagogical knowledge was not investigated enough. Despite great efforts to cover a lot of questions and undoubted theoretical and practical significance of educational research, it should be noted that the problem of physical education for younger pupils using sports games in the lessons of physical education remains open to theoretical understanding and experimental study. There is a lack of specific studies that reveal the basic trends and ways to optimize the studied phenomenon. Worsening situation in the area of physical training in junior classes and individual indicators of health status in the country encourages looking for scientific solutions of the problem.

Thus, there is an objective contradiction between the demand prevailing in the necessity of organizing physical training for students in junior grades and insufficient development of this issue in pedagogical science and practice. Our research problem was the identification of the pedagogical conditions for physical development of students in junior grades during physical education lessons involving elements of sports, where the use of different exercises and the best outdoor sports games could contribute to the optimization of the investigated phenomenon (Ilyasova \& Erzhanov, 2014).

The relevance of this problem, the lack of theoretical elaboration and practical requirements defined problem of our investigation - to theoretically substantiate and develop a technique of optimization for physical training of junior schoolchildren during physical education lessons.

Our research aim was to define the most effective methods of physical training for 8-9-yearold girls in the second and the third grades during physical education lessons which involve elements of sports games in a comprehensive school.

Research objectives were as follows:

- To prove the dependence of the dynamics of growth indicators and physical condition for female students in junior grades on the content and direction of physical education lessons;

- To justify the purposeful use of the elements of sports in the lessons of physical education which improve the physical condition of girls in junior grades and contributes to the engagement in sports.

\section{METHODS}

To obtain the research results we used the following methods: literature review, pedagogical experiment, testing, and mathematical statistics.

The research was conducted in the academic year of 2011-2012. Participants were 8-9-yearold students of the second and the third grades in the secondary school "Prestige" in Almaty. All participants were divided into four groups. In each of the three experimental (E1, E2, E3) and the control group (C) group included 16 girls. The pedagogical experiment involved 64 girls. The control group had physical education according to the programme of secondary schools twice a week for 45 minutes. The girls of the experimental groups E1, E2, E3 had physical education classes for one academic year involving specialized technical training exercises of sports (football, basketball, vigorous games), planned on the basis of the modified program CYSS which included: a blow on the ball in a range, making a shot, dribbling the ball kicked, dribbling hands, sending the ball between partners, a game with throws "Square", "moving target", "getting the ball". The study was conducted in three stages, the first test was conducted in September, 
the second one - in February, and the third one in June. During the experiment we examined the effectiveness of two factors:

- A different ratio of the time allotted for physical and technical training;

- Purposeful development of different physical skills.

During the experiment, the following indicators were tested:

- Physical development: body height, body weight, chest circumference, and chest excursion;

- General physical fitness: $30 \mathrm{~m}$ running with a high start, long jump from place, making a shot, running $3 \times 10 \mathrm{~m}$, hand grip strength;

During the experiment, group E1 had physical education lessons according to program A, i.e. $75 \%$ of the lesson time (34 min) was given to training technical elements of sport and 25\% (11 $\mathrm{min})$ - for the development of physical skills. Group E2 had physical education lessons according to program $\mathrm{B}$, in which activities for technical skills were given $50 \%$ of the lesson time $(22 \mathrm{~min})$, and the development of physical skills $-50 \%$ of the time. Group E3 had education program C. Physical skills received $75 \%$ of the lesson time (34 $\mathrm{min})$, and $25 \%$ of the lesson (11 $\mathrm{min}$ ) was given to teaching vigorous games. The data obtained were processed applying the methods of mathematical statistics. We defined the arithmetic mean for each indicator $(X)$ and their errors $(S x)$, as well as the percentage change in study data. Comparing the results of individual groups, as well as the increase of the indices for individual study period, when testing the hypothesis of equality of the individual and mean $(X)$, the method of the analysis of variance ANOVA ( $F-$ Fisher's test) was used. Statistically significance of difference between the indicators assessed was set at $p<.05$ when $F=3.20$ ).

\section{RESULTS}

Dynamics of physical development of 8-9-yearold girls is shown in Table 1.

The body height. In the first survey of the value of this indicator fluctuated from 120.6 (E2) to 126.0 (E1) $\mathrm{cm}$. Statistically significant differences were not observed between the groups ( $p>.05)$. During the academic year, the value of the body height of the experimental groups and the control group increased by $5.92-9.82 \%(p<.001)$. It should be noted that during the experimental period there were statistically significant differences in the height of girls due to growth in the first and the third experimental groups as well as the control group $(p<.05)$.

Body weight. In the first survey, the value of this indicator fluctuated from 21.8 (E2) to 26.4 (E1) $\mathrm{kg}$. Statistically significant differences were observed between the groups $(p>.05)$. During the second survey, an increase in body weight by $12.82-15.46 \%(p<.05, p<.01)$ was found. In the third survey, the value of the indicator for members in the experimental groups fluctuated from 28.4 to $34.1 \mathrm{~kg}$. It was established that at the end of the experiment, the values of the body weight compared to baseline increased the greatest in group E2 - by $23.24 \%$, and in group E1 - by $20.58 \%$, whereas for the representatives of E3 the control group the increase was by 20.39 and $20.32 \%$. Changes in body weight girls of all the researched groups were statistically significant $(p<.001, p<.01)$.

The circumference of the thorax. At the beginning of the experiment, the value of this indicator fluctuated from 58.5 (E2) to 60.6 (E1) $\mathrm{cm}$. However, between-group differences were not significant $(p>.05)$. In the third testing, the values of this indicator fluctuated from 63.1 (E2) to 65.2 (E1) $\mathrm{cm}$. However, again we did not observe intergroup differences. Overall growth indicators of the chest circumference were statistically significant $(p<.01$, $p<.001)$ in all groups during the experiment.

Chest excursion. At the beginning of the experiment, the results of this indicator fluctuated from 1.9 (E2) to 2.4 (E3) cm. However, betweengroup differences at this stage of the survey were insignificant. In the third testing, the values of this indicator fluctuated from 2.7 (E2) to 3.3 (C) $\mathrm{cm}$. Significant group differences in performance were observed only between the two experimental and control groups.

Results of changes in the general physical fitness are presented in Table 2.

Running $30 \mathrm{~m}$. The initial value of this indicator for girls fluctuated from 6.4 to $6.0 \mathrm{~s}$ (E3). During the second testing, significant group differences were found between the control, the second and third experimental groups $(p<.05)$. It was established that during the third testing, the highest result was found for girls from the third group $-5.8 \mathrm{~s}$. The average result of other experimental groups was equal to 5.9, and the control group - $6.1 \mathrm{~s}$. A significant increase in the running speed between 
Table 1. Results of changes in the physical development of girls, students of the second and the third grades $(X \pm S x)$

\begin{tabular}{|c|c|c|c|c|c|}
\hline \multirow{2}{*}{ Physical development } & \multirow{2}{*}{ Stages } & \multicolumn{4}{|c|}{ Groups } \\
\hline & & E1 & E2 & $\mathbf{E 3}$ & $\mathbf{C}$ \\
\hline $\begin{array}{l}\text { Body height } \\
\qquad(\mathrm{cm})\end{array}$ & $\begin{array}{l}1 \\
2 \\
3\end{array}$ & $\begin{array}{l}126.0 \pm 1.70 \\
133.6 \pm 1.86 \\
139.1 \pm 1.95\end{array}$ & $\begin{array}{l}120.6 \pm 1.87 \\
128.2 \pm 1.19 \\
133.0 \pm 1.27\end{array}$ & $\begin{array}{l}123.4 \pm 1.16 \\
129.3 \pm 1.17 \\
134.4 \pm 1.37\end{array}$ & $\begin{array}{l}121.1 \pm 0.79 \\
128.3 \pm 0.82 \\
134.3 \pm 0.82\end{array}$ \\
\hline $\begin{array}{c}\text { Difference }(\%) \text { and } \\
\text { significance of changes }\end{array}$ & $1-3$ & $\begin{array}{c}9.42 \\
p<.001\end{array}$ & $\begin{array}{c}5.92 \\
p<.05\end{array}$ & $\begin{array}{c}8.18 \\
p<.01\end{array}$ & $\begin{array}{c}9.82 \\
p<.001\end{array}$ \\
\hline $\begin{array}{l}\text { Body mass } \\
\quad(\mathrm{kg})\end{array}$ & $\begin{array}{l}1 \\
2 \\
3\end{array}$ & $\begin{array}{l}26.4 \pm 0.93 \\
30.1 \pm 0.87 \\
34.1 \pm 1.42\end{array}$ & $\begin{array}{l}21.8 \pm 0.82 \\
25.5 \pm 0.64 \\
28.4 \pm 0.66\end{array}$ & $\begin{array}{l}24.2 \pm 0.95 \\
27.5 \pm 0.95 \\
30.4 \pm 1.08\end{array}$ & $\begin{array}{l}24.3 \pm 0.79 \\
28.2 \pm 0.90 \\
30.5 \pm 1.21\end{array}$ \\
\hline $\begin{array}{c}\text { Difference }(\%) \text { and } \\
\text { significance of changes }\end{array}$ & $1-3$ & $\begin{array}{c}22.58 \\
p<.001\end{array}$ & $\begin{array}{c}23.24 \\
p<.001\end{array}$ & $\begin{array}{c}20.39 \\
p<.01\end{array}$ & $\begin{array}{c}20.32 \\
p<.01\end{array}$ \\
\hline $\begin{array}{l}\text { The chest } \\
\text { circumference } \\
(\mathrm{cm})\end{array}$ & $\begin{array}{l}1 \\
2 \\
3\end{array}$ & $\begin{array}{l}60.6 \pm 0.58 \\
62.2 \pm 0.75 \\
65.2 \pm 1.22\end{array}$ & $\begin{array}{l}58.5 \pm 0.71 \\
60.3 \pm 0.53 \\
63.1 \pm 0.63\end{array}$ & $\begin{array}{l}59.3 \pm 0.96 \\
61.0 \pm 0.14 \\
64.1 \pm 1.22\end{array}$ & $\begin{array}{l}58.7 \pm 0.82 \\
62.7 \pm 0.95 \\
64.8 \pm 1.05\end{array}$ \\
\hline $\begin{array}{c}\text { Difference }(\%) \text { and } \\
\text { significance of changes }\end{array}$ & $1-3$ & $\begin{array}{c}7.05 \\
p<.01\end{array}$ & $\begin{array}{c}7.29 \\
p<.01\end{array}$ & $\begin{array}{c}7.49 \\
p<.01\end{array}$ & $\begin{array}{c}9.41 \\
p<.001\end{array}$ \\
\hline $\begin{array}{l}\text { Chest excursion } \\
(\mathrm{cm})\end{array}$ & $\begin{array}{l}1 \\
2 \\
3\end{array}$ & $\begin{array}{l}2.2 \pm 0.24 \\
2.8 \pm 0.28 \\
2.9 \pm 0.25\end{array}$ & $\begin{array}{l}1.9 \pm 0.17 \\
2.3 \pm 0.19 \\
2.7 \pm 0.16\end{array}$ & $\begin{array}{l}2.4 \pm 0.14 \\
2.9 \pm 0.26 \\
3.0 \pm 0.18\end{array}$ & $\begin{array}{l}2.3 \pm 0.16 \\
2.9 \pm 0.19 \\
3.3 \pm 0.21\end{array}$ \\
\hline $\begin{array}{c}\text { Difference }(\%) \text { and } \\
\text { significance of changes }\end{array}$ & $1-3$ & $\begin{array}{c}24.13 \\
p<.05\end{array}$ & $\begin{array}{c}29.62 \\
p<.01\end{array}$ & $\begin{array}{c}20.00 \\
p<.05\end{array}$ & $\begin{array}{c}30.30 \\
p<.001\end{array}$ \\
\hline
\end{tabular}

the first and the third testing was achieved only by the girls in the first experimental group $(p<.05)$.

Long jump. In the first testing the result of this indicator fluctuated from 122.5 (E3) to 126.6 (E1) cm. However, between-group differences were not statistically significant. In the second testing, intergroup differences also remained almost unchanged. In the third testing, results of this indicator fluctuated from 133.0 (C) to 137.2 (E1) $\mathrm{cm}$. However, significant differences in the results between the groups were observed. During the whole period of the experiment the most significant increase in the result of this exercise was observed in girls from group E1 - 9.91\%.

Making a shot. The results of this indicator in the first examination fluctuated from an average of 2.4 (E3) to 3.4 (E1) results of 5 attempts. In the second testing, these indicators became almost identical in all groups. A similar pattern was observed in the third testing. However, it should be noted that the increase in this indicator during the experiment was the highest in girls in group E3 $38.46 \%(p<.001)$.

Running $3 \times 10 \mathrm{~m}$. In the first examination, results of the indicator fluctuated from 10.8 (C) to 10.6 (E1, E3) s. In the second survey, results in running $3 \times 10 \mathrm{~m}$ did not change. In the third testing, results of this indicator were almost equal in all groups. During the period of the experiment, results of this indicator in girls of all groups increased within the limits of $2.83-3.70 \%$.

Hand grip strength. The results of this indicator in the first examination fluctuated from an average of 10.4 (E3) to 10.7 (E1) kg. In the second testing, the values of this indicator gradually increased, but between-group differences were statistically insignificant. In the third testing, the highest strength was demonstrated by girls in group E3, where this result increased from 10.4 to $12.9 \mathrm{~kg}$ $(19.38 \%, p<.001)$ on average. 
Table 2. Result of changes in general physical fitness for girls, students in the second and the third grades $(\mathrm{X} \pm S x)$

\begin{tabular}{|c|c|c|c|c|c|}
\hline \multirow{2}{*}{ Tests } & \multirow{2}{*}{ Stages } & \multicolumn{4}{|c|}{ Groups } \\
\hline & & E1 & E2 & E3 & C \\
\hline$\underset{\text { (s) }}{\text { Running }} 30 \mathrm{~m}$ & $\begin{array}{l}1 \\
2 \\
3\end{array}$ & $\begin{array}{l}6.2 \pm 0.08 \\
6.1 \pm 0.07 \\
5.9 \pm 0.06\end{array}$ & $\begin{array}{l}6.1 \pm 0.07 \\
6.0 \pm 0.06 \\
5.9 \pm 0.07\end{array}$ & $\begin{array}{l}6.0 \pm 0.05 \\
5.9 \pm 0.05 \\
5.8 \pm 0.05\end{array}$ & $\begin{array}{l}6.4 \pm 0.08 \\
6.3 \pm 0.08 \\
6.1 \pm 0.07\end{array}$ \\
\hline $\begin{array}{c}\text { Difference (\%) and } \\
\text { significance of changes }\end{array}$ & $1-3$ & $\begin{array}{c}4.83 \\
p<.05\end{array}$ & $\begin{array}{c}3.28 \\
p>.05\end{array}$ & $\begin{array}{c}3.33 \\
p>.05\end{array}$ & $\begin{array}{c}3.68 \\
p<.05\end{array}$ \\
\hline $\begin{array}{l}\text { Long jump } \\
\qquad(\mathrm{cm})\end{array}$ & $\begin{array}{l}1 \\
2 \\
3\end{array}$ & $\begin{array}{l}126.6 \pm 2.88 \\
132.3 \pm 2.62 \\
137.2 \pm 2.52\end{array}$ & $\begin{array}{l}123.4 \pm 2.00 \\
128.3 \pm 1.97 \\
133.3 \pm 1.94\end{array}$ & $\begin{array}{l}122.5 \pm 1.61 \\
128.2 \pm 1.59 \\
134.3 \pm 1.52\end{array}$ & $\begin{array}{l}122.8 \pm 1.64 \\
127.8 \pm 1.69 \\
133.0 \pm 1.54\end{array}$ \\
\hline $\begin{array}{c}\text { Difference (\%) and } \\
\text { significance of changes }\end{array}$ & $1-3$ & $\begin{array}{c}9.91 \\
p<.001\end{array}$ & $\begin{array}{c}7.42 \\
p<.01\end{array}$ & $\begin{array}{c}8.78 \\
p<.01\end{array}$ & $\begin{array}{c}7.67 \\
p<.01\end{array}$ \\
\hline $\begin{array}{l}\text { Making a shot from } \\
\text { the distance of } 6 \mathrm{~m} \text {, } \\
5 \text { attempts } \\
\text { (number of shots) }\end{array}$ & $\begin{array}{l}1 \\
2 \\
3\end{array}$ & $\begin{array}{l}3.4 \pm 0.19 \\
3.6 \pm 0.13 \\
4.3 \pm 0.16\end{array}$ & $\begin{array}{l}2.7 \pm 0.25 \\
3.3 \pm 0.18 \\
4.1 \pm 0.21\end{array}$ & $\begin{array}{l}2.4 \pm 0.27 \\
3.3 \pm 0.19 \\
3.9 \pm 0.19\end{array}$ & $\begin{array}{l}2.5 \pm 0.23 \\
3.3 \pm 0.19 \\
3.9 \pm 0.17\end{array}$ \\
\hline $\begin{array}{c}\text { Difference }(\%) \text { and } \\
\text { significance of changes }\end{array}$ & $1-3$ & $\begin{array}{c}20.93 \\
p<.001\end{array}$ & $\begin{array}{c}34.14 \\
p<.001\end{array}$ & $\begin{array}{c}38.46 \\
p<.001\end{array}$ & $\begin{array}{c}35.90 \\
p<.001\end{array}$ \\
\hline $\begin{array}{l}\text { Running } \\
3 \times 10 \mathrm{~m} \\
\text { (s) }\end{array}$ & $\begin{array}{l}1 \\
2 \\
3\end{array}$ & $\begin{array}{l}10.6 \pm 0.18 \\
10.4 \pm 0.16 \\
10.3 \pm 0.15\end{array}$ & $\begin{array}{l}10.7 \pm 0.11 \\
10.5 \pm 0.10 \\
10.3 \pm 0.09\end{array}$ & $\begin{array}{l}10.6 \pm 0.11 \\
10.5 \pm 0.12 \\
10.3 \pm 0.10\end{array}$ & $\begin{array}{l}10.8 \pm 0.12 \\
10.5 \pm 0.11 \\
10.4 \pm 0.09\end{array}$ \\
\hline $\begin{array}{c}\text { Difference (\%) and } \\
\text { significance of changes }\end{array}$ & $1-3$ & $\begin{array}{c}2.83 \\
p>.05\end{array}$ & $\begin{array}{c}3.74 \\
p<.01\end{array}$ & $\begin{array}{c}2.83 \\
p<.05\end{array}$ & $\begin{array}{c}3.70 \\
p<.01\end{array}$ \\
\hline $\begin{array}{l}\text { Hand grip strength } \\
(\mathrm{kg})\end{array}$ & $\begin{array}{l}1 \\
2 \\
3\end{array}$ & $\begin{array}{l}10.7 \pm 0.17 \\
11.5 \pm 0.20 \\
12.5 \pm 0.24\end{array}$ & $\begin{array}{l}10.5 \pm 0.25 \\
11.3 \pm 0.25 \\
12.0 \pm 0.28\end{array}$ & $\begin{array}{c}10.4 \pm 0.12 \\
11.3 \pm 0.1 \\
12.9 \pm 0.18\end{array}$ & $\begin{array}{l}10.5 \pm 0.11 \\
11.2 \pm 0.12 \\
12.0 \pm 0.15\end{array}$ \\
\hline $\begin{array}{c}\text { Difference }(\%) \text { and } \\
\text { significance of changes }\end{array}$ & $1-3$ & $\begin{array}{c}14.40 \\
p<.001\end{array}$ & $\begin{array}{c}12.50 \\
p<.001\end{array}$ & $\begin{array}{l}19.38 \\
p<.001\end{array}$ & $\begin{array}{c}12.50 \\
p<.001\end{array}$ \\
\hline
\end{tabular}

\section{DISCUSSION}

Analysing the dynamics of physical development of girls in primary school at the beginning of the experiment, we did not see much difference between the experimental and the control groups. Similar results of physical development of girls were found in the research by other authors (Baxter-Jones, 2001). During the period of the experiment, increase in indicators, was approximately equal in all groups, the special advantages of any group were not observed. This suggests that physical training in experimental and general education programs equally affected the growth of girls in the experimental groups and the control group. Comparing our data with those of several authors (Armstrong \& Welsman, 2000; Bar-Or, 1996; Rowland, 2007; Telema, Yang, Hirvansalo, \& Raitkari, 2006), we found that they corresponded to indicators characteristic of girls aged 8-9 years. It should be noted that the increase in the average physical development indicators of the girls during the experimental period was statistically significant $(p<.05-.001)$ with some advantage of group E1 representatives who had the physical education lessons with $75 \%$ of time devoted to exercises in sports games. According to Baxter-Jones (2001), Rowland (2007), body height does not completely show the physical condition of a child. The main features of physical perfection 
for children is still considered as strength, speed, endurance, joint mobility, coordination and agility (Dencer, Thorsson, \& Karlson, 2006; Malina et al., 2004; Синявский et al., 2009).

Analysis of the dynamics of the results of general physical fitness of girls shows that in all the surveyed groups there was a marked increase in the values of all indicators. This indicates a favourable age of 8-9-year-old girls for the development of basic impellent skills: speed and strength. A number of authors (Armstrong \& Welsman, 2000; Chvicialovski, Wulf, de Medeiros, \& Dencer, 2006; Kalfer, \& Tani, 2008) are of the same opinion. Given dynamics of the results of general physical fitness over the study period suggests a different relationship between the indicators in the surveyed groups. For example, significant differences $(p>.05)$ were observed in $30 \mathrm{~m}$ run and long jump. However, it should be noted that the increase of these indicators is somewhat higher in the experimental groups. As for exercise containing an element of technical training sports game - making a shot, the highest result was achieved by girls in group E1 in physical education lessons with $75 \%$ of the time allotted to sports games. At the same time the results of the strongest hand grip were demonstrated by girls in group E3, where $75 \%$ of time in physical education lessons was devoted to physical training. Physical development, the overall fitness of girls in primary school testify the advantages of the integrated programs with elements of sports games (experimental group) during physical education lessons without harming their health, and creating more favourable conditions for the manifestation of their capabilities to have more children in sports. The same opinion can be found in the research by Stepinski, Zwirko, Frolkiewicz, and Debieka (2003), Адамбеков and Боранбаев (1999).

Thus, the data obtained suggest that the experimental programs containing exercises in physical education lessons have a more significant effect on the physical development and physical fitness of girls $8-9$ years of age.

\section{CONCLUSIONS}

1. Indicators of physical development of girls during the school year changed considerably. The most clearly expressed change was noted in the results of the changes in body weight of girls from 20.32 to $23.24 \%$ in all groups. Significant differences between the experimental and control groups were identified in terms of physical development.

2. Analysing the increase in overall physical fitness for the whole period of the experiment, we found a significant changes in all examined experimental groups $(p<.05-.001)$. Indicators of overall physical fitness can be divided into two groups:

- The first group included indicators which were significantly higher in the experimental group E3, where more time was devoted to physical training (running at $30 \mathrm{~m}$, the hand strength) during the physical education lessons;

- The second group included indicators which were significantly higher in the experimental group E1, where more time was devoted to sports (long jump, making a shot, running $3 \times 10 \mathrm{~m}$ ) during physical education lessons.

3. The study showed that the best option of physical training for girls of primary school age is an integrated program in physical education lessons with $75 \%$ of the total time of the lesson devoted to sports and $25 \%$ of the lesson time should be devoted to the development of physical skills (program A).

4. Physical education lessons with elements of sports games promote more intensive development dynamics in overall fitness of girls aged 8-9 years compared to physical education lessons conducted according to the general curriculum.

\section{REFERENCES}

Armstrong, N., \& Welsman, J. (2000). Development of aerobic fitness during childhood and adolescence. Pediatric Exercise Science, 12, 128-140. doi: 10.1162/ jocn_a_00344

Bar-Or, O. (1996). The child and adolescent athlete. Oxford: Blackwell Science.

Baxter-Jones, A. (2001). Growth and development of young athletes. Sport Medicine, 4, 59-64. doi: 10.2165/00007256-199520020-00001
Chvicialovskij, S., Wulf, G., de Medeiros, F., Kalfer, A., \& Tani, G. (2008). Learning benefits of self-controlled knowledge of results in 10 year old. Research Quarterly for Exercise and Sports, 79(3), 405-410.

Dencer, M., Thorsson, D., \& Karlson, M. (2006). Daily physical activity in Swedish children aged 8-11 years. Scandinavian Journal of Medicine and Science in Sports, 16, 252-257. doi: dx.doi.org/10.1007/s00421006-0310-X 
Gudžinskienè, V. (2006). Physical activity of primary schoolchildren and factors determining their physical activity. Sport Science, 4(46), 55-60.

Ilyasova, A., \& Erzhanov, Z. (2014). Optimization of physical fitness development for primary school learners in physical education lessons. Education. Physical Training. Sport, 2(93), 21-28.

Malina, R. M., Bouchard, C., \& Bar-Or, O. (2004.) Growth, maturation and physical activity. Champaign, IL: Human Kinetics.

Rowland, T. W. (2007). Evaluation of maximal oxygen uptake of children. Medicine and Sport Science, 50, 200-209.

Rowland, T. W. (2007). Physical activity, fitness and children. Physical activity and health. Champaign, IL: Human Kinetics.

Stepinski, M., Zwirko, T., Frolkiewicz, B., \& Debieka, J. (2003). The level of motor abilities of 10-13 years old soccer players. Journal of Human Kinetics, 9, 99-109.

Telema, R., Yang, X., Hirvansalo, M., \& Raitkari, O. (2006). Participation in organized youth sport as a predictor of adult physical activity: A 21-year longitudinal study. Pediatric Exercise Science, 17, 76-78.

Turley, K. R. (1997). Cardiovascular responses to exercise in children. Sports Medicine, 24 (4), 241-257. doi: 10.2165/00007256-199724040-00003

Van Praag, E. (2000). Development of anaerobic function during childhood and adolescence. Pediatric Exercise Science, 12, 150-173.

Yang, X., Telema, R., Laakgo, L., KeltikangasJärvinen, L., \& Pullli, L. (2007). Determination of adult physical activity: Relative importance of youth physical activity and demographic, psychological, behavioral and environmental factors on adulthood. Acta Kinesiologiae Universtatis Tartuensis, 12, 129-146.

Адамбеков, К. И., \& Боранбаев, К. С. (1999). Совершенствование скоростных качеств у юных футболистов с использованием эффективных средств и мето- дов тренировки. Теория и практика Казахстанского футбола. Научно-педагогической журнал, 2, 41-47.

Бальсевич, В. К. (2000). Онтокинезиология человека. Москва: ФиС. С. 68-71.

Бервинова, Н. С., \& Шарабакин, Н. И. (2005). Основы школьной физической культуры: учебник для студентов физкультурных вузов, учителей и тренеров спортивных школ. Бишкек.

Волков, В. Н., \& Ромашев, А. В. (1998). Лонгитудинальные исследования скоростно-силовых показателей школьников 11-14 лет. Теория и практика физической культуры, 7, 5-6.

Гужаловский, А. А. (1987). Физическое воспитание школьников: критические периоды развития. Теория и практика физической культуры, 7, 37-39.

Касымбекова, С., Кошаев, М. Н., \& Абишев, А. Р. (2013). Физическое воспитание учащейся молодёжи в системе образования республики Казахстан. $M a-$ териаль международной конференции “Проблемь и перспективы физической культуры в современном обществе” (сс. 70-72). Алматы, Каз. НПУ.

Кульназарова, А. К. (2013). Перспективы направления совершенствования физкультурно-спортивного движения в республике Казахстан в период до 2022 года. Материаль международной конференции "Проблемь и перспективы физической культуры в современном обществе” (сс. 4-8). Алматы, Каз. НПУ.

Минаев, В. Н. (1989). Основы методики физического воспитания школьников. Москва: ФиС.

Синявский, Н. И., Власов, В. В., \& Сергеев, К. В. (2009). Мониторинг физической подготовленности детей младшего школьного возраста Среднего Приобья. Физическая культура: воспитание, образование, тренировка, 3, 31-32.

Юревич, А. И. \& Мусатаев, К. Б. (2013). Концепция развития детско-юношеского футбола в Казахстане: Материаль международной конференщии "Проблемы и перспективы физической культуры в современном обществе” (сс. 34-36). Алматы, Каз. НПУ.
Received on November 13, 2014

Accepted on March 09, 2015
Corresponding author Almagul Ilyasova

Kazakh National Pedagogical University after Abay Spartak Stadium, Ormarova str., Almaty Kazakhstan

Tel. +7(777) 5717180

E-mail timfk.2013@mail.ru 